\title{
No evidence for promoter region methylation of the succinate dehydrogenase and fumarate hydratase tumour suppressor genes in breast cancer
}

\author{
Katie T Huang ${ }^{1,2}$, Alexander Dobrovic ${ }^{1,2}$ and Stephen B Fox*1,2
}

\author{
Address: ${ }^{1}$ Molecular Pathology Research and Development Laboratory, Department of Pathology, Peter MacCallum Cancer Centre, Melbourne, \\ Victoria 3002, Australia and 2Departmant of Pathology, University of Melbourne, Parkville, Victoria 3010, Australia \\ Email: Katie T Huang - Katie.Huang@petermac.org; Alexander Dobrovic - Alexander.Dobrovic@ petermac.org; \\ Stephen B Fox* - Stephen.Fox@petermac.org \\ * Corresponding author
}

Published: 25 September 2009

BMC Research Notes 2009, 2:194 doi:10.1186/1756-0500-2-194

This article is available from: http://www.biomedcentral.com/1756-0500/2/194

(C) 2009 Fox et al; licensee BioMed Central Ltd.

This is an Open Access article distributed under the terms of the Creative Commons Attribution License (http://creativecommons.org/licenses/by/2.0), which permits unrestricted use, distribution, and reproduction in any medium, provided the original work is properly cited.
Received: 23 May 2009

Accepted: 25 September 2009

\begin{abstract}
Background: Succinate dehydrogenase $(\mathrm{SDH})$ and fumarate hydratase $(\mathrm{FH})$ are tricarboxylic acid (TCA) cycle enzymes that are also known to act as tumour suppressor genes. Increased succinate or fumarate levels as a consequence of $S D H$ and $F H$ deficiency inhibit hypoxia inducible factor- $I \alpha$ $(H I F-I \alpha)$ prolyl hydroxylases leading to sustained HIF-I $\alpha$ expression in tumours. Since HIF-I $\alpha$ is frequently expressed in breast carcinomas, DNA methylation at the promoter regions of the SDHA, $S D H B, S D H C$ and SDHD and $F H$ genes was evaluated as a possible mechanism in silencing of SDH and $F H$ expression in breast carcinomas.
\end{abstract}

Findings: No DNA methylation was identified in the promoter regions of the SDHA, SDHB, SDHC, SDHD and FH genes in 72 breast carcinomas and 10 breast cancer cell lines using methylationsensitive high resolution melting which detects both homogeneous and heterogeneous methylation.

Conclusion: These results show that inactivation via DNA methylation of the promoter CPG islands of $S D H$ and $F H$ is unlikely to play a major role in sporadic breast carcinomas.

\section{Introduction}

The hypoxia-inducible factor (HIF-1) transcription factor plays a pivotal role in breast tumour progression [1-4] by activating genes involved in angiogenesis, cell proliferation and survival $[1,2,5]$. Levels of HIF- $1 \alpha$ subunits (HIF$1 \alpha$ ) are tightly regulated with rapid degradation via hydroxylation by prolyl hydroxylases (PHDs) 1, 2 and 3 and proteasomal degradation by the von Hippel-Lindau (VHL) protein [1]. Increased levels of fumarate and succinate inhibit PHD activity via product inhibition as well as by direct inhibition by competing with $\alpha$-ketoglutarate at the PHD $\alpha$-ketoglutarate binding site [6-8]. Thus any mechanism whereby the level of succinate dehydrogenase (SDH) or fumarate hydratase $(\mathrm{FH})$ is reduced may result in tumorigenesis $[9,10]$. Indeed, the $S D H$ and $F H$ genes have been demonstrated to be tumour suppressor genes (TSG) via this pseudohypoxic drive in paraganglioma [11], hereditary leiomyomatosis and renal cell carcinomas [7]. In view of this potential mechanism to enhance HIF$1 \alpha$ levels and in view of the association of HIF-1 $\alpha$ levels with breast cancer prognosis and resistance to treatment, we hypothesised that epigenetic silencing by promoter methylation for the $S D H$ and $F H$ genes may be a mecha- 
Table I: Primer sequences, annealing temperature and amplicon information for the MS-HRM assays.

\begin{tabular}{|c|c|c|c|c|}
\hline Gene & $\begin{array}{l}\text { Primer Sequences } \\
\text { 5' - 3' }\end{array}$ & $\begin{array}{c}\text { Annealing } \\
\text { temperature } \\
\left({ }^{\circ} \mathrm{C}\right)\end{array}$ & $\begin{array}{c}\text { Amplified region } \\
\text { (GenBank accession and } \\
\text { nucleotide numbers) }\end{array}$ & $\begin{array}{l}\text { Screened } \\
\text { CpGs/ } \\
\text { amplicon } \\
\text { size (bp) }\end{array}$ \\
\hline \multirow[t]{2}{*}{ SDHA } & F - CGGGGTTTTAAAAATGTTGGTGTT & 61 & AC021087.5: $218153-218484$ & $39 / 332$ \\
\hline & R - CGAACCCCCGACATATCTACTATTACC & & & \\
\hline \multirow[t]{2}{*}{ SDHB I } & F - CGGGGGAAGTTAAATGGGTATG & 60 & AL049569.13: $17380588-17380744$ & $14 / 157$ \\
\hline & R - CGCCCAACCTACATCCACTAAA & & & \\
\hline \multirow[t]{2}{*}{ SDHB 2} & F - GCGGTTAGTGGGTTTTTAGTGGAT & 65 & AL049569.13: $17380446-17380623$ & $16 / 178$ \\
\hline & R - CAAACAAACTCCGCCAAAAATTATAACC & & & \\
\hline \multirow[t]{2}{*}{ SDHC } & F - TCGTTATATGATATTTTTAATTTCGATTTTTAGT & 56 & AL592295.25: $161284096-161284197$ & $8 / 102$ \\
\hline & R - ATCTTAAATTCCGATCTAAACGAAAATAAC & & & \\
\hline \multirow[t]{2}{*}{ SDHD } & F - CGGGTTGGTGGATGATTTTGAG & 62 & AP002007.4: III $957596-111957689$ & $4 / 94$ \\
\hline & R - CCTCACCTCGACCTCCTAAAACAC & & & \\
\hline \multirow[t]{2}{*}{$\mathrm{FH}$} & F - TTTGTTTTATTTTGTCGGTGTGAGGT & 60 & AL591898.1: $241683032-241683154$ & $7 / 123$ \\
\hline & R - AAAACTTAAATAAAATTTCTAAACGACTATAACCAC & & & \\
\hline
\end{tabular}

nism underlying upregulated HIF-1 in a proportion of breast carcinomas.

\section{Materials and methods DNA samples}

DNA was obtained from 72 invasive breast carcinomas from the John Radcliffe Hospital, Oxford, UK (Ethics committee approval: JR C02.216) and from the following cancer cell lines: breast: MCF10A, MCF7, BT20, SkBr3, Hs578T, T47D, MDA-MB 153, MDA-MB 468, MDA-MB 453, MDA-MB 231; colorectal: Colo205, HCT116, SW948, SW48; leukaemia: HL60, KG1, RPMI8226, CCRFCEM; ovarian: 2008; neuroblastoma: SK-N-SH, SH-SY5Y, $\mathrm{Be}(2) \mathrm{c}$, IMR32; and prostate: PC3.

(-230) cgggggaagttaaatgggtatg cgtcgttattgegttattgegtacgttcgttgtgtttgttcetttttttcgtttatt MSHRM-F (1) MSP-F

MSHRM-F (2)

(-148) cgggaaatcggaagtcgtttttatttggttgttcgtacgcggttagtgggtttttagtggatgtaggttgggcgtco MSHRM-R (1)

(-70) cgatgttcgacgggatateggeggagagcgatttcggggttaaggggtggggttgacgttaggagttaagatg

\section{MSHRM-R (2)}

(+4) geggcggtggtcgtttttttttgaggcgtcggttgtcggttataattttggcggagtttgtttg

\section{MSP-R}

\section{Figure I}

SDHB bisulfite modified promoter sequence with primers indicated. SDHB MS-HRM (I) primer sequences are shown in boxes and SDHB MS-HRM (2) primers are underlined. SDHB MSP primer sequences are shaded in grey. CpG dinucleotides are in bold. The number in parentheses on the left is the nucleotide position relative to the starting codon ATG (shaded in black). 
A

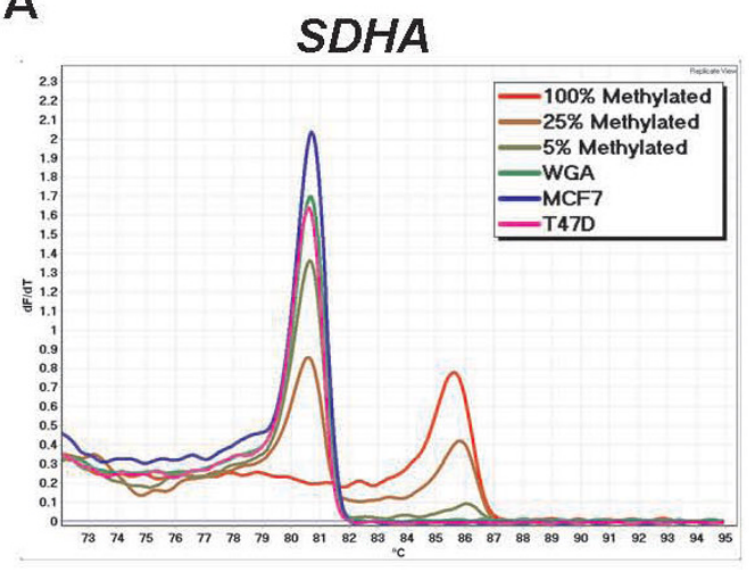

C


E
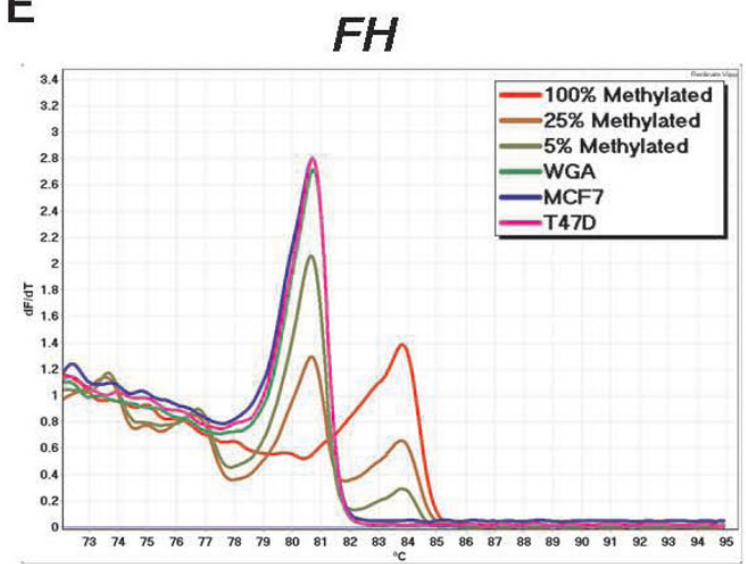

B

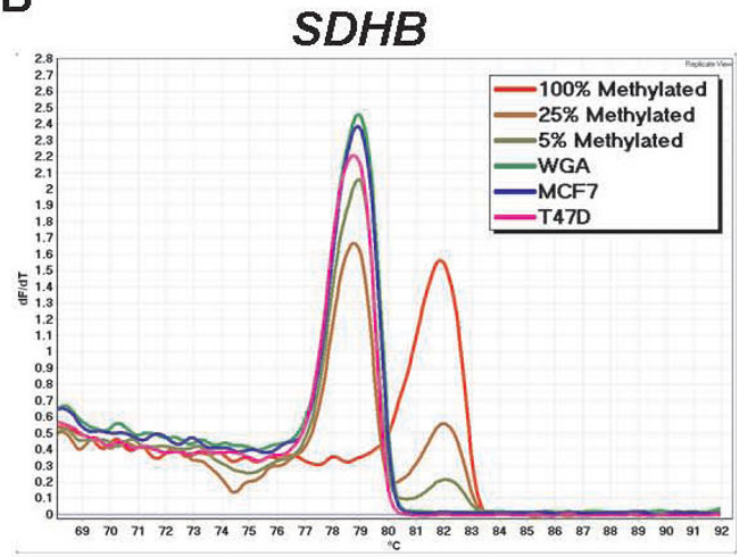

D



\section{Figure 2}

SDH and FH MS-HRM in breast cancer cell lines. In MS-HRM, PCR products undergo melting analysis after PCR amplification. Different amplicons have different melting behaviours according to their methylation status. Unmethylated samples melt earlier than methylated samples as they have unmethylated cytosines replaced by thymines in the sequence. Controls for $100 \%$, $25 \%, 5 \%$ methylation and WGA are shown. Levels of methylation as low as $5 \%$ can be readily seen. The cell lines shown here, MCF7 and T47D showed no methylation of the four SDH subunits and FH. A. SDHA; B. SDHB; C. SDHC; D. SDHD; and E. FH methylation. The curve for each sample represents the mean value of duplicate samples. 
A

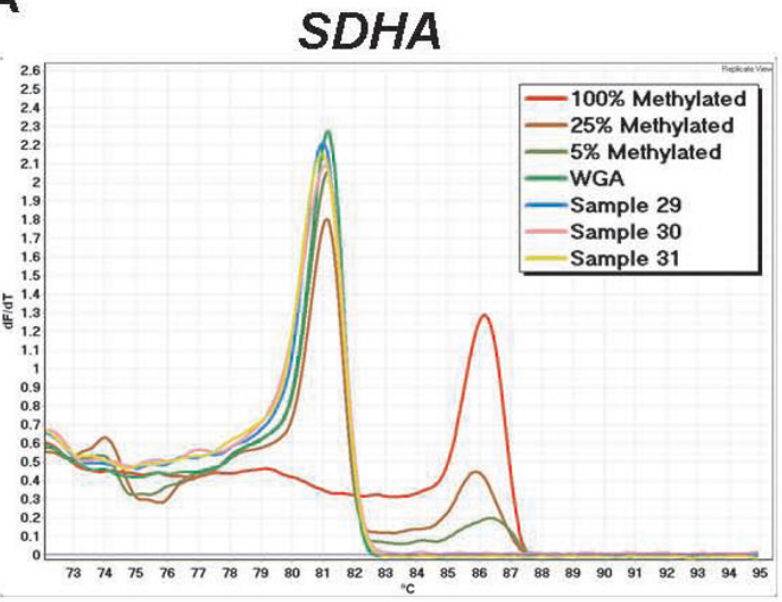

C

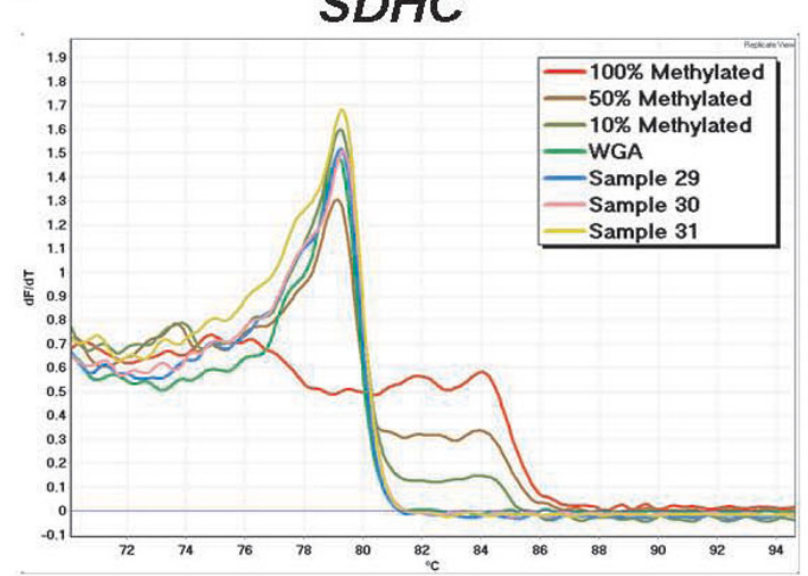

$E$

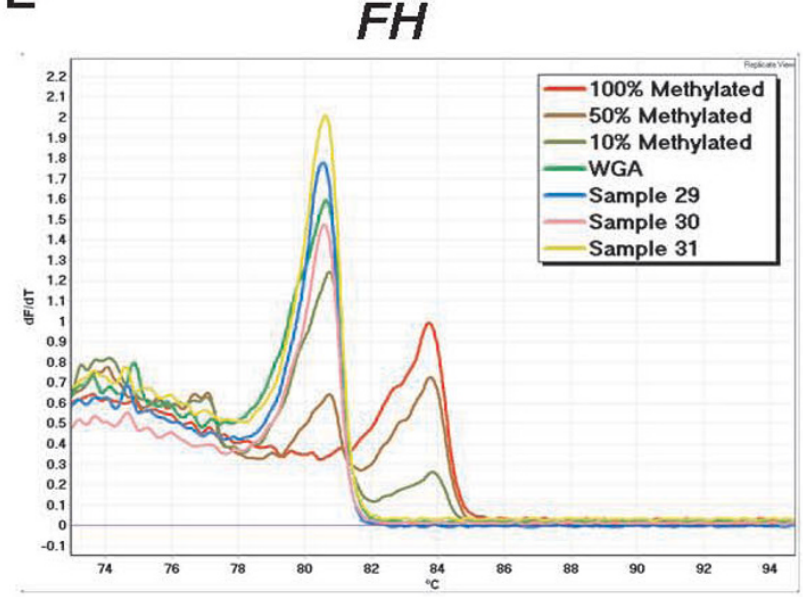

B

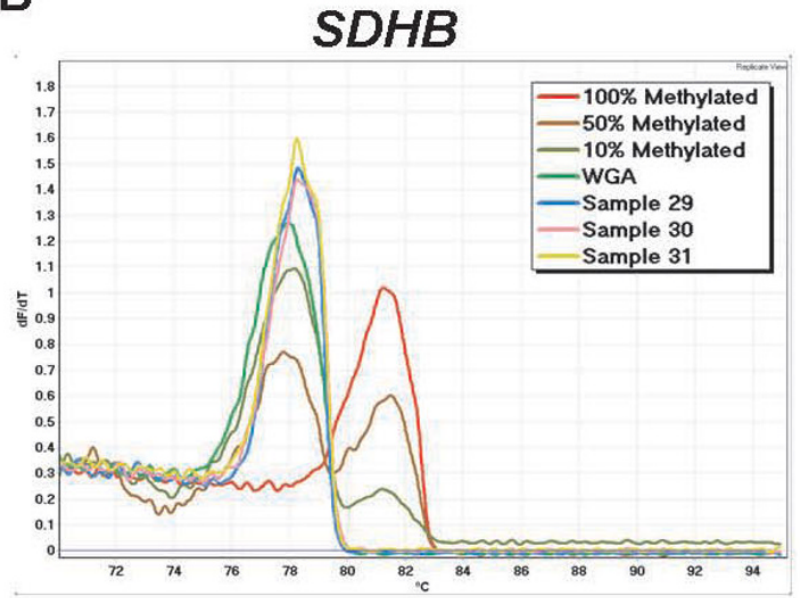

D

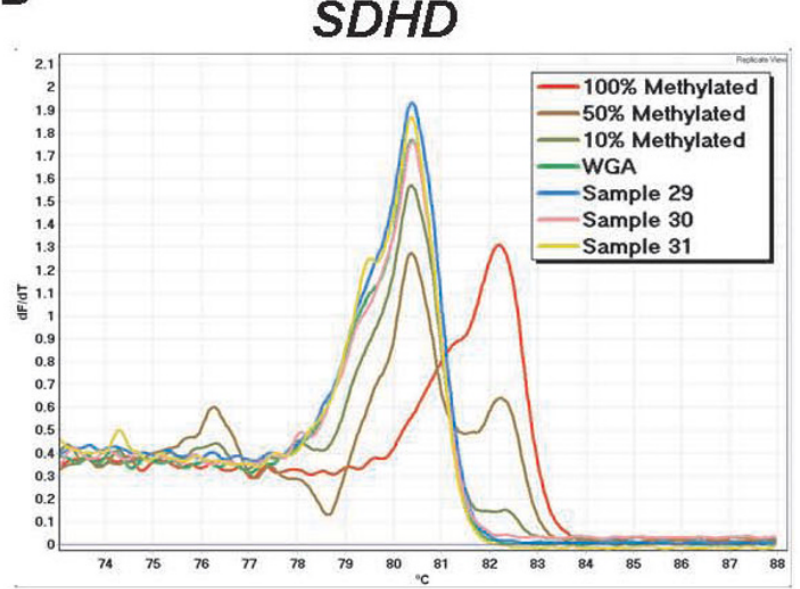

Figure 3

SDH and FH MS-HRM in breast carcinoma samples. All the breast carcinoma samples showed no methylation. Three representative cancers are shown. The curve for each sample represents the mean value of duplicate samples. 
Table 2: RASSFIA and MAL methylation frequencies in the breast carcinoma samples as determined by MS-HRM

\begin{tabular}{cccc}
\hline & RASSFIA Positive & RASSFIA Negative & Total \\
\hline MAL Positive & $28(38.9 \%)$ & $2(2.8 \%)$ & $30(41.7 \%)$ \\
MAL Negative & $32(44.4 \%)$ & $10(13.9 \%)$ & $42(58.3 \%)$ \\
Total & $60(83.3 \%)$ & $12(16.7 \%)$ & 72 \\
\hline
\end{tabular}

\section{Bisulfite modification}

DNA from samples were bisulfite modified as described previously [12]. CpGenome ${ }^{\mathrm{TM}}$ Universal Methylated DNA (Chemicon/Millipore, Billerica, MA) and DNA from peripheral blood mononuclear cells were used as the methylated and unmethylated controls, respectively. Standards (5, 10, 25 and 50\% methylation) were generated by diluting Universal Methylated DNA in the unmethylated DNA. Whole-genome amplification (WGA) DNA was used as an alternative unmethylated control [12].

\section{Methylation-sensitive high resolution melting (MS-HRM) and methylation-specific PCR (MSP)}

Methylation-sensitive high resolution melting (MS-HRM) was performed on bisulfite modified DNA [13]. MS-HRM primer sequences and optimal annealing temperatures are listed in Table 1. Bisulfite modified fully methylated, peripheral blood DNA, WGA DNA, different methylation percentage standards and no template controls were used in each run as controls and standards. Assays were performed in duplicate.

\section{A}

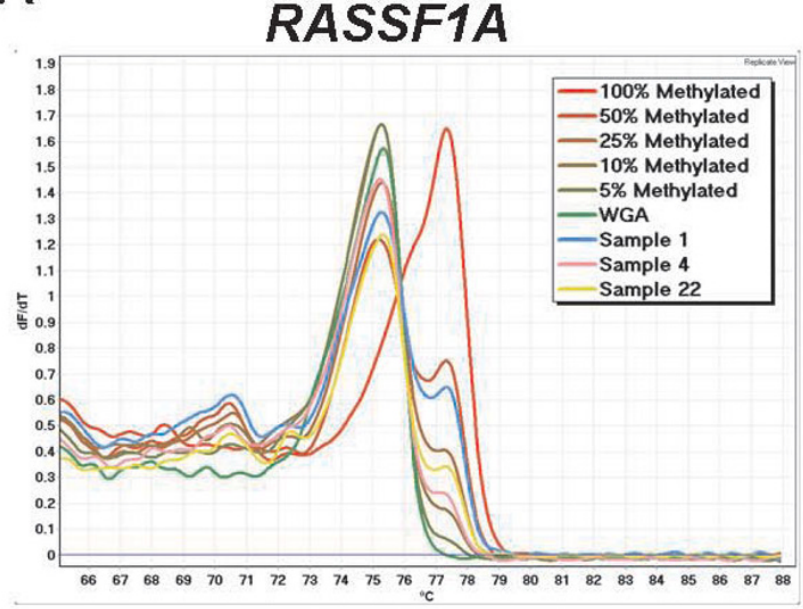

Methylation-specific PCR primer sequences and PCR conditions of $S D H B$ methylation were described previously in [14]. The positions of the SDHB MS-HRM and MSP primer sequences in the $S D H B$ promoter sequence are shown in Figure 1.

\section{Results}

Methylation of SDHA, SDHB, SDHC, SDHD and FH in cell lines and tumours

CpG islands were identified in the promoter region of $S D H A, S D H B, S D H C, S D H D$ and $F H$ demonstrating the potential for alteration of their gene expression by methylation. MS-HRM primers were designed to cover CpG rich areas of the proximal promoter region for each gene. However, methylation was not observed for any of the 5 genes in any of the 10 cell lines tested (Figure 2) or in any of the 72 invasive breast carcinomas (Figure 3 ).

The absence of detectable methylation was not due to technical reasons such as absence of breast cancer material. MS-HRM assays for two genes known to be methylated in a large proportion of breast cancers were used as

\section{Figure 4}

RASSFIA and MAL MS-HRM of breast carcinoma samples. A. RASSFIA MS-HRM demonstrates generally homogeneous methylation in the breast carcinoma samples at different percentages of methylation ranging from 10 to $50 \%$ methylation. B. Both homogeneous (the sharp peak seen for sample 5) and heterogeneous methylation (the more complex melting profiles across both unmethylated and methylated peaks seen in the other samples) can be observed for MAL. 
A

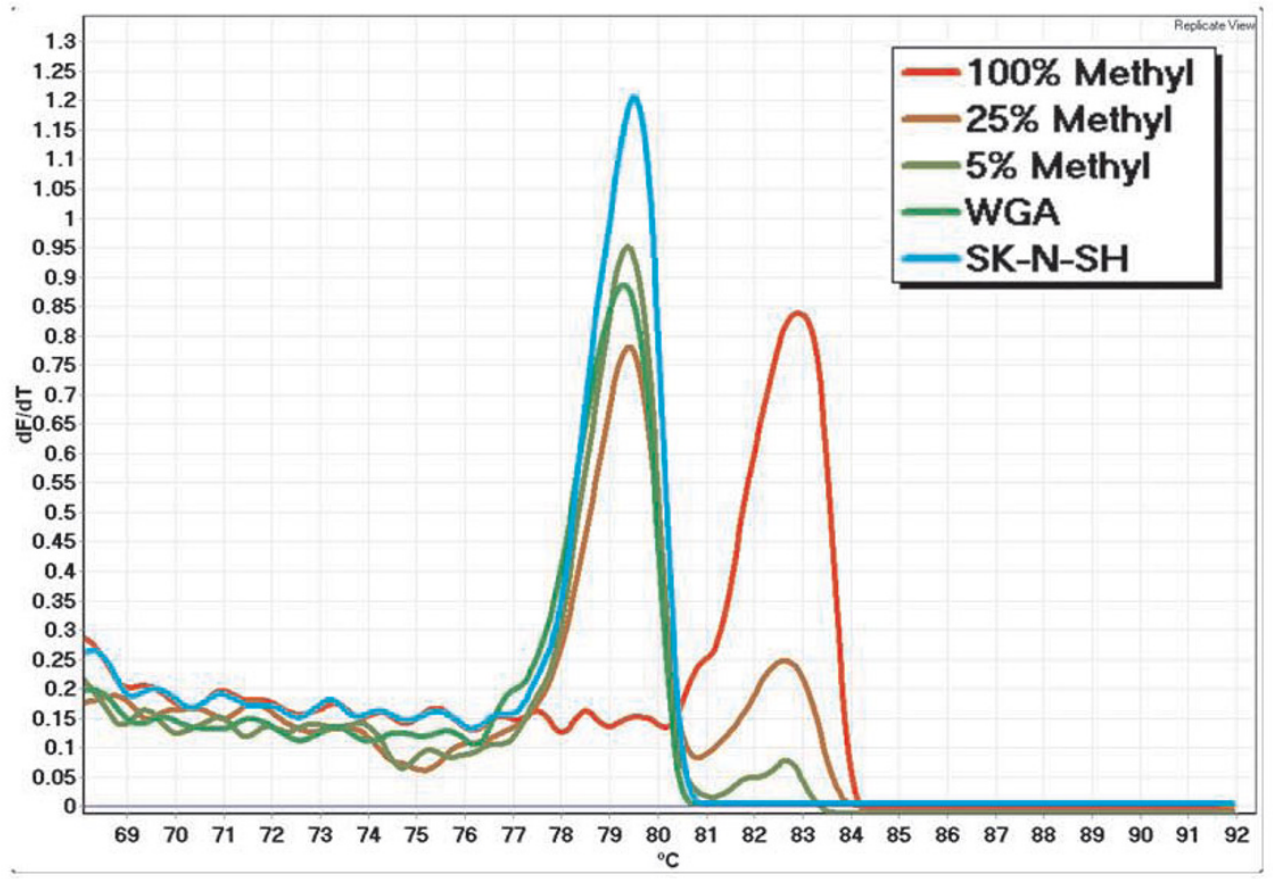

B
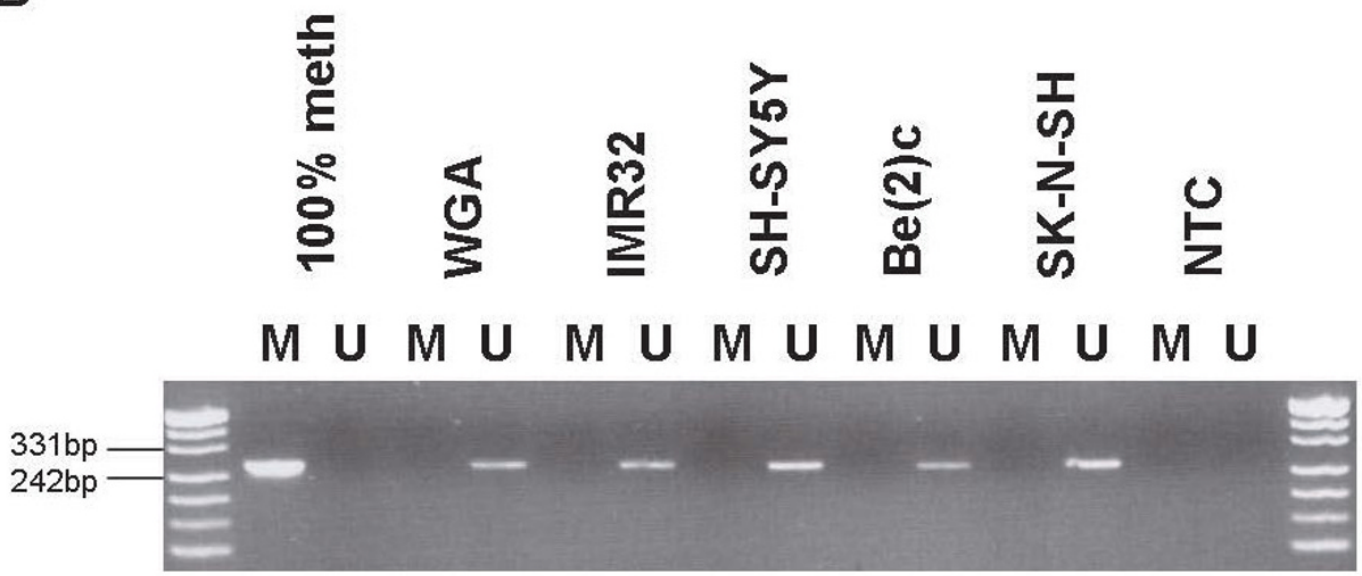

\section{Figure 5}

SDHB MS-HRM and MSP analysis in neuroblastoma cell lines. A. SDHB MS-HRM of the SK-N-SH neuroblastoma cell line; the early melting shows that SDHB is clearly unmethylated in the SK-N-SH cell line isolate used by us (the curves for each sample represents the mean value of duplicate samples). B. Four bisulfite modified neuroblastoma DNA (IMR32, SH-SY5Y,

$\mathrm{Be}(2) \mathrm{c}$ and SK-N-SH) were amplified using specific SDHB methylated (M) and unmethylated (U) MSP primer pairs. Fully methylated DNA (I00\% methyl) and fully unmethylated DNA (WGA) were used as controls. The no template control (NTC) was also included as a negative control for both methylated and unmethylated PCR. 
controls to show that methylated genes could be detected in the 72 breast carcinoma samples using our methodology. A high frequency of RASSF1A (83.3\%) and MAL $(41.7 \%)$ methylation was identified in the breast carcinomas $[15,16]$. Only ten breast carcinoma samples showed no methylation for either control markers (Table 2). RASSF1A showed principally homogeneous methylation whereas MAL showed mostly heterogeneous methylation in these 72 invasive breast carcinomas (Figure 4). These results indicate methylation of the $S D H A, S D H B, S D H C$, $S D H D$ and $F H$ genes in these samples would have been detected if it was present.

\section{Discussion}

Overexpression of HIF-1 $\alpha$ has been previously reported to correlate with angiogenesis [5], an aggressive phenotype $[3,17]$ and poor outcome after conventional adjuvant therapy $[18,19]$ in breast cancer. Thus mechanisms that enhance HIF- $1 \alpha$ expression are important in cancer development and would be potential targets for treatment $[2,20]$.

The tricarboxylic acid cycle enzymes, SDH and $\mathrm{FH}$ are involved in the conversion of succinate to fumarate and fumarate to malate, respectively. SDH also takes part in the electron transport chain as a functional complex II member.

Both SDH and FH can act as tumour suppressors, and germline mutations in their genes predispose to tumour development. Mutations in the genes coding for SDH subunits $B, C$ and $D$ predispose to familial paragangliomas and phaeochromocytomas $[11,21,22]$, and mutations in FH cause hereditary leiomyomatosis and renal cell carcinomas [23].

Although the mechanisms that link SDH and FH mutations to tumour formation are unclear, it is likely that pseudohypoxia is a primary mechanism. Both Selak et al. [8] and Pollard et al. [24] have suggested that overexpression of HIF- $1 \alpha$ in normoxic conditions is due to the accumulation of succinate, which then is able to inhibit the activity of HIF- $1 \alpha$ prolyl hydroxylases via product inhibition. A recent study has also shown that disruption of mitochondrial metabolism using small interfering RNAs to silence SDHB resulted in up-regulation of HIF-1 $\alpha$. [25]. Furthermore, microarray analysis has confirmed that genes involved in the hypoxic pathway are dysregulated when SDHB is silenced [25].

Since many tumour suppressor genes are known to be inactivated by DNA promoter methylation, we examined promoter methylation of $\mathrm{SDH}$ and $\mathrm{FH}$ in a cohort of breast carcinomas. However, we found no evidence of
DNA methylation of the promoter regions of these genes in breast carcinomas cancer or a panel of cancer cell lines, including ten breast cancer cell lines, making it unlikely that methylation of the promoter regions of these genes is responsible for increased HIF expression in breast cancers. Although we cannot exclude the possibility that methylation of regions other than the proximal promoter may be involved, our findings are also in keeping with others who have been unable to demonstrate methylation of SDHD in neuroblastomas and $F H$ in renal cell cancers [26,27].

Promoter methylation of $S D H B$ has been previously reported in primary sporadic phaeochromocytoma (32\%) and neuroblastoma (21\%) [14]. We were unable to demonstrate the previously reported SDHB promoter methylation in the SK-N-SH neuroblastoma cell line [14] using both MS-HRM and methylation-specific PCR (MSP) assays (Figure 5). Since MS-HRM methodology is capable of detecting levels of methylation as low as 5\%, it suggests that the methylation-specific PCR (MSP) that was previously used may have miscalled the methylation. MSP is prone to false positives, particularly if incomplete conversion is present. The reported absence of correlation between the apparent $S D H B$ methylation and $S D H B$ gene expression in the cell line used in that study further supports the possibility that the methylation was artefactual [14].

In conclusion, promoter methylation of the SDHA, $S D H B, S D H C, S D H D$ and $F H$ genes is unlikely to be an important mechanism in stabilising HIF-1 in breast carcinomas through the downregulation of the expression of $S D H$ and $F H$ genes.

\section{Competing interests}

The authors declare that they have no competing interests.

\section{Authors' contributions}

KTH participated in the design of the experiment, performed the experiments and data analysis and drafted the manuscript. AD participated in the design of the experiment and helped to analyse the data. SBF conceptualised the study and supervised the work. All authors contributed to the manuscript and read and approved the final draft.

\section{Acknowledgements}

We wish to thank the Molecular Pathology Research and Development group in Peter MacCallum Cancer Centre for their help and support and Ida Candiloro for proofreading the manuscript. We would like to thank Professor Adrian L. Harris for supplying us with the breast carcinoma samples. We would also like to thank Associate Professor David Ashley and Andrea Muscat for supplying us with the neuroblastoma cell lines. This work was funded by grants from the Victorian Breast Cancer Research Consortium and the Cancer Council of Victoria. 


\section{References}

I. Harris AL: Hypoxia - A key regulatory factor in tumour growth. Nature Reviews Cancer 2002, 2(1):38-47.

2. Semenza GL: Targeting HIF-I for cancer therapy. Nature Reviews Cancer 2003, 3(I 0):721-732.

3. Yamamoto $Y$, lbusuki M, Okumura $Y$, Kawasoe T, Kai K, lyama K, Iwase $\mathrm{H}$ : Hypoxia-inducible factor I alpha is closely linked to an aggressive phenotype in breast cancer. Breast Cancer Research and Treatment 2008, I I 0(3):465-475.

4. Unruh A, Ressel A, Mohamed HG, Johnson RS, Nadrowitz R, Richter $\mathrm{E}$, Katschinski DM, Wenger RH: The hypoxia-inducible factor-I alpha is a negative factor for tumor therapy. Oncogene 2003, 22(2I):32I3-3220.

5. Fox SB, Generali DG, Harris AL: Breast tumour angiogenesis. Breast Cancer Research 2007, 9(6): II.

6. King A, Selak MA, Gottlieb E: Succinate dehydrogenase and fumarate hydratase: linking mitochondrial dysfunction and cancer. Oncogene 2006, 25(34):4675-4682.

7. Gottlieb E, Tomlinson IP: Mitochondrial tumour suppressors: a genetic and biochemical update. Nat Rev Cancer 2005, 5( I I ):857-866.

8. Selak MA, Armour SM, MacKenzie ED, Boulahbel H, Watson DG, Mansfield KD, Pan Y, Simon MC, Thompson CB, Gottlieb E: Succinate links TCA cycle dysfunction to oncogenesis by inhibiting HIF-alpha prolyl hydroxylase. Cancer Cell 2005, 7(I):77-85.

9. Eng C, Kiuru M, Fernandez MJ, Aaltonen LA: A role for mitochondrial enzymes in inherited neoplasia and beyond. Nat Rev Cancer 2003, 3(3): 193-202.

10. Pollard PJ, Wortham NC, Tomlinson IPM: The TCA cycle and tumorigenesis: the examples of fumarate hydratase and succinate dehydrogenase. Annals of Medicine 2003, 35(8):634-635.

II. Baysal BE: On the association of succinate dehydrogenase mutations with hereditary paraganglioma. Trends Endocrinol Metab 2003, I 4( I 0):453-459.

12. Kristensen LS, Mikeska T, Krypuy M, Dobrovic A: Sensitive Melting Analysis after Real Time-Methylation Specific PCR (SMARTMSP): high-throughput and probe-free quantitative DNA methylation detection. Nucleic Acids Research 2008, 36(7):e42.

13. Wojdacz TK, Dobrovic A: Methylation-sensitive high resolution melting (MS-HRM): a new approach for sensitive and highthroughput assessment of methylation. Nucleic Acids Research 2007, 35(6):e4I.

14. Astuti D, Morris M, Krona C, Abel F, Gentle D, Martinsson T, Kogner $P$, Neumann HP, Voutilainen R, Eng $C$, et al:: Investigation of the role of SDHB inactivation in sporadic phaeochromocytoma and neuroblastoma. Br J Cancer 2004, 9 I ( I 0): | 835-|84I.

15. Dammann R, Yang G, Pfeifer GP: Hypermethylation of the cpG island of Ras association domain family IA (RASSFIA), a putative tumor suppressor gene from the $3 \mathrm{p} 2 \mathrm{l} .3$ locus, occurs in a large percentage of human breast cancers. Cancer Res 2001, 6 I(7):3105-3109.

16. Horne HN, Lee PS, Murphy SK, Alonso MA, Olson JA Jr, Marks JR: Inactivation of the MAL gene in breast cancer is a common event that predicts benefit from adjuvant chemotherapy. Mol Cancer Res 2009, 7(2): 199-209.

17. Bos R, Zhong H, Hanrahan CF, Mommers ECM, Semenza GL, Pinedo HM, Abeloff MD, Simons JW, van Diest PJ, Wall E van der: Levels of hypoxia-inducible factor-I alpha during breast carcinogenesis. Journal of the National Cancer Institute 200I, 93(4):309-3 I4.

18. Lundgren K, Holm C, Landberg G: Hypoxia and breast cancer: prognostic and therapeutic implications. Cellular and Molecular Life Sciences 2007, 64(24):3233-3247.

19. Trastour C, Benizri E, Ettore F, Ramaioli A, Chamorey E, Pouyssegur J, Berra E: HIF-I alpha and CA IX staining in invasive breast carcinomas: Prognosis and treatment outcome. International Journal of Cancer 2007, I 20(7): | 45 | - 458.

20. Patiar S, Harris AL: Role of hypoxia-inducible factor-I alpha as a cancer therapy target. Endocrine-Related Cancer 2006, I3:S6I-S75.

21. Niemann S, Muller U: Mutations in SDHC cause autosomal dominant paraganglioma, type 3. Nat Genet 2000, 26(3):268-270.

22. Astuti D, Douglas F, Lennard TW, Aligianis IA, Woodward ER, Evans DG, Eng C, Latif F, Maher ER: Germline SDHD mutation in familial phaeochromocytoma. Lancet 200I, 357(9263): || $8|-| \mid 82$.
23. Tomlinson IP, Alam NA, Rowan AJ, Barclay E, Jaeger EE, Kelsell D, Leigh I, Gorman P, Lamlum H, Rahman S, et al.: Germline mutations in $\mathrm{FH}$ predispose to dominantly inherited uterine fibroids, skin leiomyomata and papillary renal cell cancer. Nat Genet 2002, 30(4):406-4I0.

24. Pollard PJ, Briere J], Alam NA, Barwell J, Barclay E, Wortham NC, Hunt T, Mitchell M, Olpin S, Moat SJ, et al.: Accumulation of Krebs cycle intermediates and over-expression of HIFIalpha in tumours which result from germline $\mathrm{FH}$ and SDH mutations. Hum Mol Genet 2005, I 4(I 5):2231-2239.

25. Cervera AM, Apostolova N, Crespo FL, Mata M, McCreath KJ: Cells silenced for SDHB expression display characteristic features of the tumor phenotype. Cancer Res 2008, 68(I I):4058-4067.

26. De Preter K, Vandesompele J, Hoebeeck J, Vandenbroecke C, Smet J, Nuyts A, Laureys G, Combaret V, Van Roy N, Roels F, et al.: No evidence for involvement of SDHD in neuroblastoma pathogenesis. BMC Cancer 2004, 4:55.

27. Dulaimi E, Ibanez de Caceres I, Uzzo RG, Al-Saleem T, Greenberg RE, Polascik TJ, Babb JS, Grizzle WE, Cairns P: Promoter hypermethylation profile of kidney cancer. Clin Cancer Res 2004, I O(I 2 Pt I):3972-3979.
Publish with Bio Med Central and every scientist can read your work free of charge

"BioMed Central will be the most significant development for disseminating the results of biomedical research in our lifetime. "

Sir Paul Nurse, Cancer Research UK

Your research papers will be:

- available free of charge to the entire biomedical community

- peer reviewed and published immediately upon acceptance

- cited in PubMed and archived on PubMed Central

- yours - you keep the copyright

Submit your manuscript here:

http://www.biomedcentral.com/info/publishing_adv.asp
BioMedcentral 